\title{
Fatty Acids Content in Milk of Dromedary Camel (Camelus dromedarius) from Farming and Pastoral Systems in Sudan
}

\author{
*Elagba Mohamed ${ }^{1}$, Ayman Mustafa ${ }^{2}$ \\ ${ }^{1}$ Natural History Museum, Faculty of Science University of Khartoum. P.O. Box 321, Khartoum, Sudan. \\ ${ }^{2}$ College of Veterinary Medicine, University of Butana, P.O. Box: 200, Tambol, Sudan.
}

Running title: Fatty acids in milk of Camelus dromedarius from Sudan.

\begin{abstract}
The content of fatty acids was determined in milk from camel (Camelus dromedarius), under farming system and Natural pasture, by gas chromatography-mass spectrometry $(\mathrm{GC})$. Milk from farming and pastoral system, respectively, contained (84.3and 85.7 $\mathrm{mg} / \mathrm{g}$ ) total fatty acids, where, saturated fatty acids formed $67.5 \%$ and $63.8 \%$, unsaturated fatty acids formed $32.5 \%$ and $36.2 \%$, USFA/ SFA was 0.48 and 0.57 ,respectively. Monounsaturated acids (MUFA) formed 29.8\% and 34.4\%, polyunsaturated acids (PUFA) formed 2.7\% and 1.8\%, respectively. Palmitic acid (C16:0) and Stearic acid (C18:0) were the major SFA, Oleic (C18:1n9c) and Palmitoleic (C16:1) acids were the major MUFA, Linoleic acid (C18:2n6c) was the major PUFA. Short chain Caproic acid (C6:0) was 0.13\% in milk from farming system and $0.2 \%$ in milk from pastoral system, medium chains (MCFA) was $8.9 \%$ and 10.7\%, and long chains (LCFA) $90 \%$ and $89 \%$ in milk of the two systems, respectively. Omega 3 and $6(\mathrm{~N}-3 / \mathrm{N}-6)$ ratio was 0.17 and 0.08 , respectively. The content of fatty acids in milk of Camelus dromedarius was comparable to other mammalian milk, and the results indicated that camel milk from different raising systems is a good potential source of essential fatty acids and can provide the daily requirement of healthy diet.
\end{abstract}

Keywords: Camelus dromedarius, farming system, fatty acids, milk, pastoral system, Sudan.

\section{Introduction}

Camel milk has an important role in human nutrition in the hot regions and arid and semi-arid countries including. Camel milk is also widely exploited for medication and human health [1], [2]. Camel sustains its productivity in difficult conditions and comparatively less affected by the adverse factors like lack of feed, water, season and length of lactation. Some factors such as type of food, age and parity are expected to affect the quality and composition of camel milk [3], [4]. However, geographical origin and seasonal variations were found to be the most effective factors in camel milk composition [5]. The Camel (Camelus dromedarius, one humped) is a very important resource of milk for humans in several arid and semiarid regions of Sudan, where it represents the only protein source. Now camels are raised under farming systems in Sudan to improve the suitability of raw milk through adjustment of feed composition.

Milk composition and quality are important characteristics that determine the nutritive value and consumer acceptability. Very rare references on various quantitative traits of milk from different parities and under different productive systems are available [6], [7], [8], [9]. Some studies were conducted to investigate the relationship of lactation stage and body condition with milk yield and composition [10], as well as the effect of seasonal and parity on milk composition [11], [12] [13]. Camel milk was found to contain all the essential nutrients found in bovine milk, [14], [15], [16]. The composition of fatty acids in camel's milk is one of the aspects related to human health [17]. However, the fatty acid composition of camel milk is not well documented [5]. Polyunsaturated fatty acids (PUFA) of the omega-6 and especially of omega-3, family are recognized essential biochemical components of human diet. The study of fatty acids composition of camel milk is of importance for conclusions on their properties as a source of the essential components for humans.

Thus, the aim of the present study is to exploit the fatty acids composition of milk from (Camelus dromedarius, one humped), raised under different productive systems (traditional pastoral and farming systems) by gas chromatography/mass spectrometry, to find better ways of sustaining this old industry for the conservation of important animal resource in the near future. The variation provided can be used successfully in the future strategies of the milk yield and improvement.

\section{Material and Methods}

Study animals and milk collection

The study was conducted on 46 lactating camels Camelus dromedarius aged 7-13 years (23 camels from a traditional pastoral herd and 23 camels from a dairy farming system in Khartoum North during the dry season. The dominant vegetations of the natural pasture are Acacia tortilis, Maeura crassifolia, leptodania pyrotechnica and Acacia seyal. The diet of the farming system composed of ground nut cake and molasses-based diet plus good water supply. Camels ranging from primiparous to camels in their 5th parity, were selected from each of the two herds for this study.

Samples of milk $(40 \mathrm{ml})$ were collected from each lactating "Naga" early morning at milking time (8:00) in clean glass bottles, thoroughly mixed and immediately transferred to the laboratory for analysis at room temperature. All samples of 


\section{International Journal of Science and Research (IJSR) \\ ISSN (Online): 2319-7064 \\ Index Copernicus Value (2013): 6.14 | Impact Factor (2015): 6.391}

the two groups came from herd and same parity. Milk samples of the same parity in the two groups were collected every week to get a strictly 7 -day interval.

\section{Chemical and statistical analysis}

The chemical components of camel milk, solid nonfat (SNF), crude fat $(\mathrm{CF})$, crude protein $(\mathrm{CP})$ and lactose were determined weekly after parturition by automatic milk analyzer device (Lactosan MCC), calibrated for camel milk. Density and temperature of milk were also reported. Gross energy was obtained for each parity. Data was statistically analyzed using STATISTIX software (Version, 10). Mean and standard deviation (SD) were reported weekly and correlations between the different components of the milk in different parities of each raising system were calculated.

\section{Fatty acids analysis with gas chromatography}

Fatty acids were analyzed as their methyl esters with a gas chromatography-mass spectrometry (GC-MS; HewlettPackard 5890 GC), according to the procedure of [18]. The different fatty acids in the camel milk were obtained by comparing the retention times of the fatty acids under study and those of a mixture of methyl esters (Supelco, PUFA-3). The concentration of individual fatty acid was calculated using heneicosanoic acid (C21:0) as internal standard. The results were calculated both as concentration ( $\mathrm{mg} / \mathrm{g})$ and $(\%)$ of total fatty acids.

\section{Results and Discussion}

Twenty-four fatty acids of different saturation levels were detected in camel milk (Table 1), where 13 were saturated (SFA) and 11 were unsaturated fatty acids (USFA). Milk from farming and pastoral system, respectively, contained $67.5 \%$ and $63.8 \%$ saturated fatty acids (SFA), $29.8 \%$ and $34.4 \%$ monounsaturated acids, and $2.7 \%$ and $1.8 \%$ polyunsaturated acids (Table 2). The major SFA were Palmitic acid (C16:0) and Stearic acid (C18:0), the major MUFA were Oleic (C18:1n9c) and Palmitoleic (C16:1) acids and the major PUFA was Linoleic acid (C18:2n6c). The predominant fatty acids were Palmitic acid (C16:0), Stearic acid (C18:0), Oleic acid (C18:1n9c), where they formed $72.5 \%$ and $76.1 \%$ of total fatty acids in milk from farming and pastoral system, respectively. The short-chain fatty acids (SCFA) which was represented by Caproic acid (C6:0) only (Table 3) was $0.13 \%$ in milk from farming system and $0.2 \%$ in milk from pastoral system. The proportion was $8.9 \%$ and $10.7 \%$ for medium chains (MCFA), $90 \%$ and $89 \%$ for long chains (LCFA) in milk of the two systems, respectively. The omega 3 and $6(\mathrm{~N}-3 / \mathrm{N}-6)$ ratio was 0.17 and 0.08 for milk from farming and pastoral system, respectively.

Different contents of $(66.1 \%)$ saturated fatty acids and $(30.5 \%)$ unsaturated fatty acids were reported in camel milk [14], compared to the present results. This could due to difference in feed intake by the camel and to difference in breeds, geographic locality, lactating stage and the environment. [5], [19] determined the fatty acid composition and cholesterol content in camel's milk of Bactrian, dromedary and hybrids from different regions of Kazakhstan, and in different seasons. Great differences in fatty acid composition occurred between regions.
The short-chain fatty acids (SCFA) was represented by Caproic acid (C6:0) only in both systems, and the proportion for medium chains (MCFA) was higher in pastoral system, while, the long chains (LCFA) had almost same value in milk of the two systems. Short-chain fatty acids (C8:0 and C10:0) were found to have higher proportion in camel's milk in spring [20], and long-chain fatty acids (C17:0 and C17:1) were higher in autumn. A high content of medium chain fatty acids is usually considered as beneficial for human health as they are more easily absorbed and metabolized. As can be seen in (Figure 1) milk of farming system contained more SFA and less USFA compared to pastoral system, but there was more PUFA in farming system. The ratio USFA/ SFA was higher in pastoral system compared to in farming system, but N-3/N-6 (Figure 2) in farming system was 0.17 doubled the ratio 0.08 in pastoral system. According to [20] the ratio unsaturated fatty acids/saturated fatty acids is a good indicator of the nutritional quality of milk. This ratio was 0.57 for dromedary milk from pastoral system and 0.48 for farming system in the present study, compared with 0.30 for cow's and 0.32 for goat's milk [21]. Fatty acid composition also showed that the content of many of them varied between the two systems. The variation observed indicated that variation in food intake and management can affect the quality of camel milk. These results confirmed that environmental and farming conditions allowed modulation of the lipid composition of camel's milk. However, the content of fatty acids in camel milk is importance for human nutrition and health [17], [22], [23].

\section{Conclusion}

The present results indicated that milk of Camelus dromedarius is comparable to other mammalian milk, and that camel milk from different raising systems is a good potential source of essential fatty acids and can provide the daily requirement of healthy diet. The results also showed that traditional pastoral system can provide milk with better nutritional contents compared to the farming system. This could be explained by the fact that natural pasture is more variable in plants and vegetations preferred by the camels than the commercial feed of the farm management system. However, more work is needed to study the effects of breed differences, lactation stage, parity and body condition as well as seasonal changes on fatty acids composition in camel milk. The composition of fatty acids in camel milk is important to determine the nutritional value of camel milk as a source of the essential fatty acids for humans.

\section{References}

[1] Kenzhebulat S, Ermuhan B, Tleuov A, Composition of camel milk and its use in the treatment of infectious diseases in human. In: Proceedings of the 2nd Camelid Conference on Agroeconomics of Camelid Farming, Almaty, Kazakhstan, September 8-12, 2000; Agro Merkur Publ., 101.

[2] Mal G, Sena DS, Jain VK, Sahani MS, Therapeutic value of camel milk as a nutritional supplement for multiple drug resistant (MDR) tuberculosis patients, Isr. J. Vet. Med. 2006; 61: 88-91. 


\section{International Journal of Science and Research (IJSR) \\ ISSN (Online): 2319-7064 \\ Index Copernicus Value (2013): 6.14 | Impact Factor (2015): 6.391}

[3] Kouniba A, Berrada M, Zahar, Bengoumi M, Composition and heat stability of Moroccan camel milk, J. Camel Pract. Res. 2005; 12: 105-110.

[4] Mustafa B, Mohamed EHA, A/Atti KA, Abunokhila AM, Rahmatalla SA, Elterife AMA, Effect of parity on milk yield and dam body change postpartum of dromedary camel (Camelus dromedarius) under farming system in Sudan, I.J.A.P.B.C. 2015; 4(1): 131-137.

[5] Konuspayeva G, Faye B, Loiseau G, The composition of camel milk, a meta-analysis of the literature data, J. Food Comp. Anal. 2009; 22: 95-101.

[6] Attia H, Kherouatou N, Fakhfakh N, Khorchani T, Trigui N. Dromedary milk fat: biochemical, microscopic and rheological characteristics, J. Food Lipids, 2000; 7: 95-112.

[7] Mustafa AB, Mohamed EHA, Haroun E, A/Atti KA, Nikhala MA, Effect of parity on camel milk composition under traditional pastoral and farmed systems in Sudan, I.J.A.P.B.C. 2014; 3(2): 266-272.

[8] Yoganandi J, Bhavbhuti MM, Wadhwani KN, Darji VB, Aparnathi KD, Evaluation and comparison of camel milk with cow milk and buffalo milk for gross composition, J. Camel Pract. Res. 2015; 21(2): 2592651

[9] Mohamed EHA, Mustafa B, A/Atti KA, Milk composition of the udder quarters of she-camel (Camelus dromedarius) raised under intensive farming system, I.J.S.K. 2016; 5(1): 9-12.

[10]Zhang H, Yao J, Zhao D, Liu H, Guo M, Changes in chemical composition of Alxa Bactrian camel milk during lactation, J. Dairy Sci. 2005; 88: 3402-3410.

[11] Bakheit SA, Majid AMA, Nikhala AM, Camels (Camelus dromedarius) under pastoral systems in North Kordofan, Sudan: seasonal and parity effects on milk composition, J. Camelid Sci. 2008; 1: 32-36.

[12] Shuiep ES, El Zubeir IEM, El Owni OAO, Musa HH, Influence of season and management on composition of raw camel (Camelus dromedarius) milk in Khartoum state, Sudan, Trop. Subtrop. Agroecosys. 2008; 8: 101106

[13] Musaad A, Faye B, Al-Mutairi S, Seasonal and physiological variation of gross composition of camel milk in Saudi Arabia, Emir. J. Food Agric. 2013; 25(8): 618-624.

[14] Gorban AMS, Izzeldin OM, Study on cholesteryl ester fatty acids in camel and cow milk lipid, Int. J. Food Sci. Technol. 1999; 34: 229-234.

[15] Gorban AMS, Izzeldin OM, Fatty acids and lipids of camel milk and colostrum. Int. J. Food Sci. Nutr. 2001; 52(3): 283-287. Published online: 06 Jul 2009

[16] Narmuratova M, Konuspayeva G, Loiseau G, Serikbaeva A, Barouh N, Montet D, Faye B, Fatty acids composition of dromedary Bactrian camel milk in Kazakhstan, J. Camel Pract. Res. 2006; 13: 45-50.

[17] Wahle KW, Heys SD, Cell signal mechanisms, conjugated linoleic acids (CLAs) and antitumorigenesis, Prostagland. Leuk. Essent Fat. Acids. 2002; 67: 183-186.

[18] Ahlgren G, Blomqvist P, Boberg M, Gustafsson IP, Fatty acid content of the dorsal muscle - an indicator of fat quality in freshwater fish, J. Fish Biol. 1994; 45:31157.
[19] Konuspayeva G, Faye B, Loiseau G, Ivashehenko A, Meldebkova A, Davletov S, Physiological change in camel milk composition, 1- Effect of lactation stage, Trop. Animal Health Prod. 2009; 42: 495- 499.

[20] Konuspayeva G, LemarieÉ, Faye B, Loiseau G, Montet D, Fatty acid and cholesterol composition of camel's (Camelus bactrianus, Camelus dromedarius and hybrids) milk in Kazakhstan, Dairy Sci. Technol. 2008; 88: 327-340.

[21] Cardak AD, Yetismeyen A, Brückner H, Quantitative comparison of free fatty acids in camel, goat and cow milk, Milch. 2003; 58: 127-130.

[22] Chilliard Y, Ferlay A, Doreau M, Contrôle de la qualité nutritionnelle des matières grasses du lait par l'alimentation des vaches laitières : acides gras trans, polyinsaturés, acide linoléique conjugué, INRA Prod. Anim. 2001; 14: 323-335.

Table 1: Fatty acid composition (mg/g) and profile (\%) of camel milk from farming and pastoral systems.

\begin{tabular}{|l|c|c|c|c|}
\hline \multirow{2}{*}{ Fatty acids } & \multicolumn{2}{|c|}{ Farming system } & \multicolumn{2}{c|}{ Pastoral system } \\
\cline { 2 - 5 } & $\mathrm{Mg} / \mathrm{g}$ & $\%$ & $\mathrm{Mg} / \mathrm{g}$ & $\%$ \\
\hline Caproic acid (C6:0) & 0.11 & 0.13 & 0.17 & 0.2 \\
\hline Capric acid (C10:0) & 0.11 & 0.13 & 0.1 & 0.12 \\
\hline Lauric acid (C12:0) & 0.3 & 0.35 & 0.35 & 0.41 \\
\hline Tridecanoic acid (C13:0) & 0.08 & 0.09 & 0.11 & 0.13 \\
\hline Myristic acid (C14:0) & 6 & 7.11 & 7.23 & 8.43 \\
\hline Pentadecanoic acid (C15:0) & 0.7 & 0.83 & 0.9 & 1.05 \\
\hline Palmitic acid (C16:0) & 23.5 & 27.92 & 26.34 & 30.74 \\
\hline Heptadecanoic acid (C17:0) & 0.43 & 0.51 & 0.57 & 0.67 \\
\hline Stearic acid (C18:0) & 18.63 & 22.11 & 18.09 & 21.11 \\
\hline Arachidic acid (C20:0) & 0.51 & 0.6 & 0.41 & 0.48 \\
\hline Behenic acid (C22:0) & 0.24 & 0.28 & 0.21 & 0.24 \\
\hline Tricosanoic acid (C23:0) IS & 3.37 & 3.99 & 0.1 & 0.11 \\
\hline Lignoceric acid (C24:0) & 2.89 & 3.43 & 0.12 & 0.14 \\
\hline Myristoleic acid (C14:1) & 0.3 & 0.36 & 0.5 & 0.58 \\
\hline Palmitoleic acid (C16:1) & 4.86 & 5.77 & 6.69 & 7.81 \\
\hline Heptadecanoic acid (C17:1) & 0.23 & 0.27 & 0.35 & 0.4 \\
\hline Elaidic acid (C18:1n9t) & 0.69 & 0.82 & 1.07 & 1.25 \\
\hline Oleic acid (C18:1n9c) & 18.91 & 22.44 & 20.74 & 24.21 \\
\hline Eicosenoic acid (C20:1) & 0.14 & 0.17 & 0.11 & 0.13 \\
\hline Linolelaidic acid (C18:2n6t) & 0.2 & 0.11 & 0.11 & 0.12 \\
\hline Linoleic acid (C18:2n6c) & 1.19 & 1.41 & 1.2 & 1.4 \\
\hline Linolenic acid (C18:3n3) & 0.12 & 0.14 & 0.11 & 0.13 \\
\hline Docosadienoic acid (C22:2) & 0.76 & 0.9 & 0.11 & 0.13 \\
\hline Eicosapentaenoic (C20:5n3) & 0.1 & 0.12 & 0 & 0 \\
\hline & & & & \\
\hline
\end{tabular}

Table 2: Concentration of fatty acids groups $(\mathrm{mg} / \mathrm{g})$ in camel milk from farming and pastoral systems

\begin{tabular}{|l|c|c|c|c|}
\hline \multirow{2}{*}{ Fatty acid groups } & \multicolumn{2}{|c|}{ Farming system } & Pastoral system \\
\cline { 2 - 5 } & $\mathrm{Mg} / \mathrm{g}$ & $\%$ & $\mathrm{Mg} / \mathrm{g}$ & $\%$ \\
\hline TFA & 84.27 & 100 & 85.7 & 100 \\
\hline SFA & 56.89 & 67.51 & 54.7 & 63.83 \\
\hline MUFA & 25.13 & 29.82 & 29.47 & 34.38 \\
\hline PUFA & 2.25 & 2.68 & 1.53 & 1.78 \\
\hline USFA & 27.38 & 32.5 & 31 & 36.16 \\
\hline USFA/ SFA & \multicolumn{3}{|c|}{0.48} & \multicolumn{2}{c|}{0.57} \\
\hline N-6 & 1.28 & 1.31 & 1.52 & 1.52 \\
\hline N-3 & 0.22 & 0.11 & 0.26 & 0.13 \\
\hline N-3/N-6 & \multicolumn{3}{|c|}{0.17} & \multicolumn{3}{c|}{0.08} \\
\hline
\end{tabular}




\section{International Journal of Science and Research (IJSR) \\ ISSN (Online): 2319-7064}

Index Copernicus Value (2013): 6.14 | Impact Factor (2015): 6.391

Table 3: Fatty acid composition (\%) of camel milk compared to some mammalian species.

\begin{tabular}{|c|c|c|c|c|}
\cline { 1 - 4 } Fatty Acids & Camel & Cow & Sheep & Goat \\
\cline { 1 - 4 } Short Chain & & & & \\
\hline C4:0 & 0 & 11 & 8 & 8 \\
\hline C6:0 & $(0.13-0.2)$ & 5 & 5 & 5 \\
\hline C8:0 & 0 & 1 & 4 & 4 \\
\hline Medium Chain & & & & \\
\hline C10:0 & $(0.12-0.13)$ & 3 & 6 & 13 \\
\hline C12:0 & $(0.35-0.41)$ & 3 & 5 & 7 \\
\hline C14:0 & $7.1-8.4$ & 10 & 10 & 12 \\
\hline Long Chain & & & & \\
\hline C16:0 & $27.9-30.7$ & 23 & 22 & 24 \\
\hline C18:0 & $21.1-22.1$ & 10 & 10 & 12 \\
\hline C18:1 & $22.4-24.2$ & 29 & 22 & 17 \\
\hline C18:2 & 1.4 & 2 & 4 & 3 \\
\hline C18:3 & $(0.13-0.14)$ & $<1$ & $<1$ & $<1$ \\
\hline
\end{tabular}

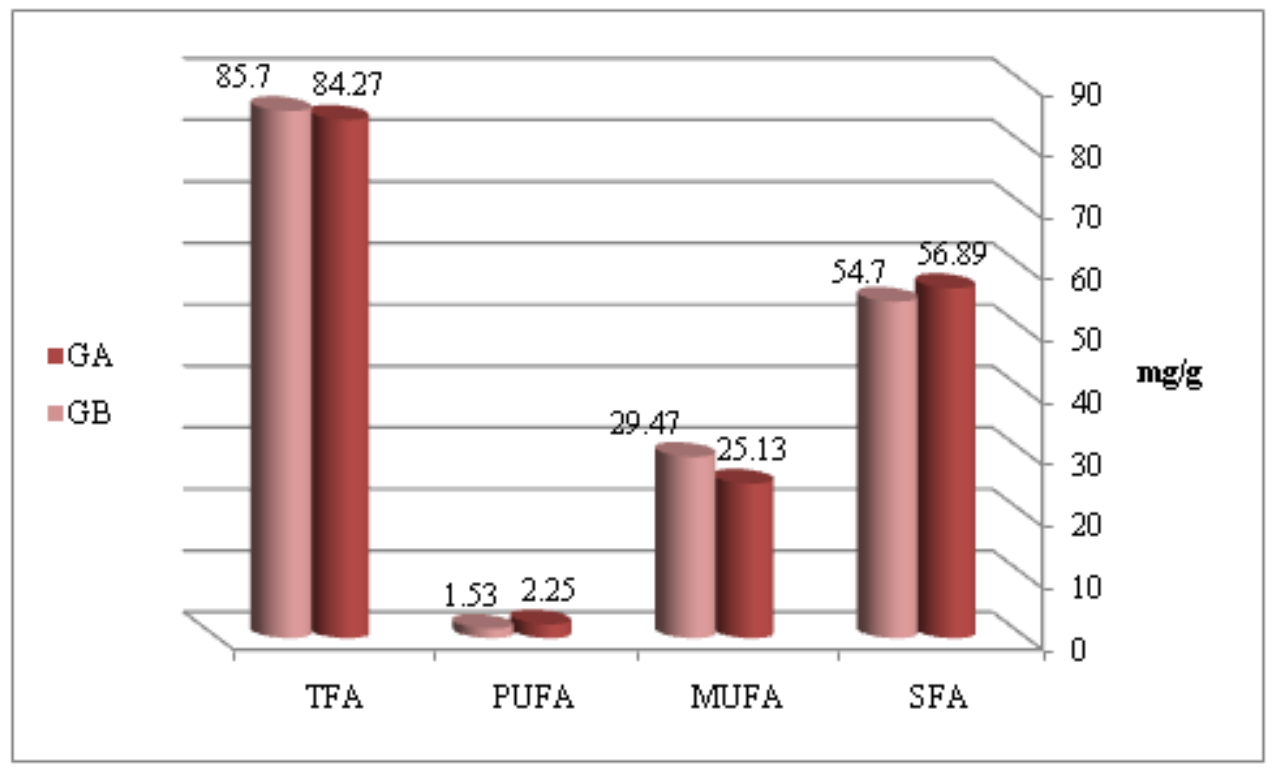

Figure 1: The contents (mg/g) of major groups of fatty acids in camel milk from farming system (GA) and pastoral system (GB)

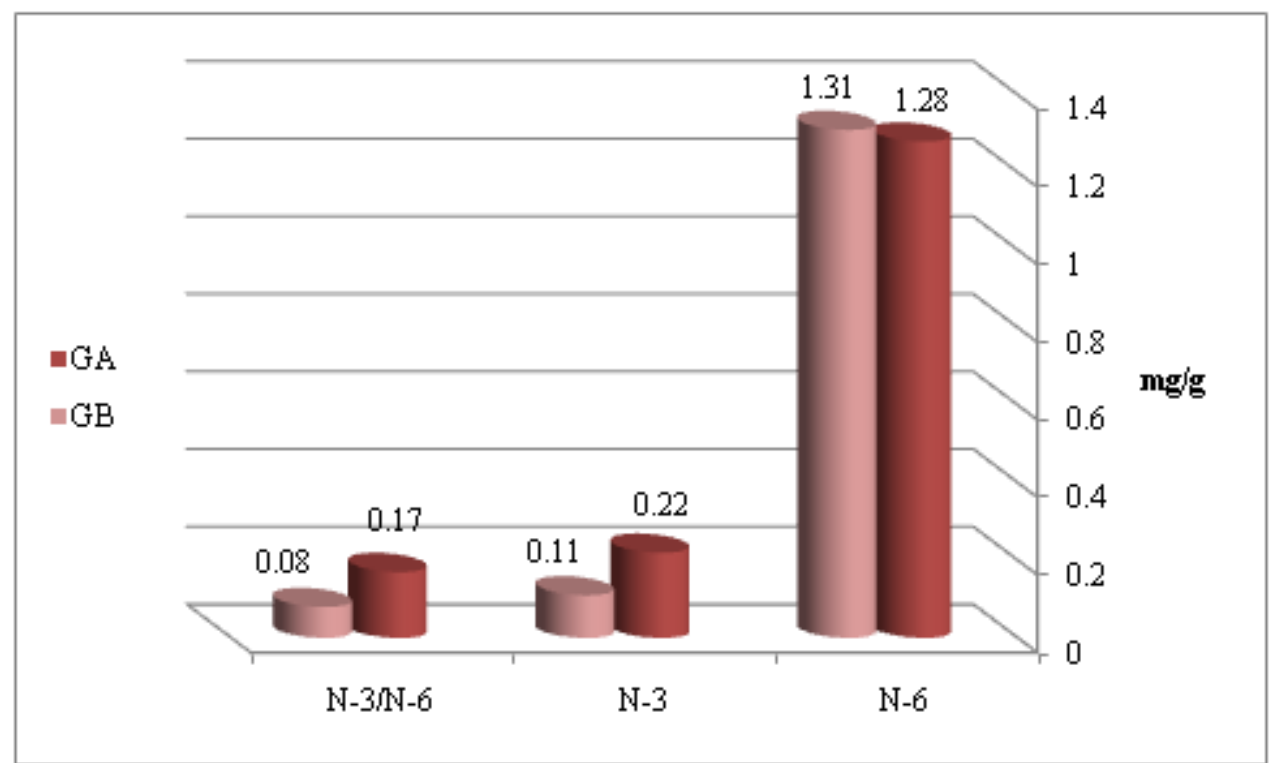

Figure 2: The contents (mg/g TFA) of omega-3 and omega-6 fatty acids in and N-3/N-6 ratio in camel milk from farming system (GA) and pastoral system (GB)

\section{Volume 5 Issue 6, June 2016} www.ijsr.net

Licensed Under Creative Commons Attribution CC BY 